\title{
Instantes mágicos de Ingmar Bergman
}

\author{
Atílio Avancini \\ Doutor; Universidade de São Paulo; São Paulo, SP, Brasil \\ avancini@usp.br
}

\section{Resumo}

O artigo tem por objeto o documentário $A$ ilha de Bergman (2006) de Marie Nyreröd. O objetivo é estudar o pensamento cinematográfico do diretor Ingmar Bergman (1918-2007) ao analisar criticamente duas de suas obras clássicas: $O$ sétimo selo (1956) e Persona (1965). Esta pesquisa privilegia a utilização de conceitos sobre a mensagem cinematográfica dentro do método teórico da mensagem obtusa de Roland Barthes. O pensamento do cineasta baseado em questões existenciais traz como resultado a dualidade vida-morte e realidade-ficção, e também o impacto poético de suas ideias para a atualidade. As contradições da vida são as inquietações do diretor sueco, que lança perguntas sem respostas definitivas. A conclusão é de que a sua obra autoral, baseada nesses dois filmes, procura buscar a perfeição e a dimensão psicológica-existencial, além de desvendar o caminho da interioridade.

\section{Palavras-chave}

Cinema. Fotografia. Imagem. Análise. Memória.

\section{Introdução}

Além da preservação e difusão da história audiovisual em cinematecas ou no ambiente virtual das plataformas digitais, outra frente importante para beneficiar o público é a reflexão histórica sobre a produção de cineastas clássicos como, neste caso, o autor Ingmar Bergman (1918-2007). 0 objetivo deste artigo é discutir o pensamento do mestre sueco e analisar o impacto de suas ideias refletidas, principalmente, em duas de suas obras artísticas, consideradas atemporais e transgressoras. E também para inspirar novas gerações de cinéfilos, pesquisadores e cineastas. De fato, sem a contínua preservação da memória, principalmente com o fim das videolocadoras e da iminente extinção da mídia física, poderemos estar fadados ao apagamento das representações do cinema do século XX.

Roland Barthes (1984) constata que a imagem é sistema rudimentar em relação à língua e à escrita, mas reconhece mesmo assim a impossibilidade de se esgotar os seus 
significados. Como ler o sentido das imagens? Compactuando a ideia da linguagem cinematográfica, Barthes afirma que o significado, quer estético ou ideológico, "[...] remete para uma certa 'cultura' da sociedade que recebe a mensagem." (BARTHES, 1984, p. 14). Este estudo, portanto, submete a imagem a uma leitura cultural, cujo objeto é analisar dois filmes clássicos do cineasta sueco Ingmar Bergman: O sétimo selo (1956) e Persona (1965).

Por constituir-se abordagem artística e poética, este estudo vai privilegiar a utilização de conceitos sobre a mensagem cinematográfica dentro do método teórico da "mensagem obtusa" de Roland Barthes. A argumentação terá como objeto primeiro e eixo referencial o documentário A ilha de Bergman (2006) dirigido por Marie Nyreröd. Sabe-se que a complexidade de leitura interpretativa de obras cinematográficas jamais serão esgotadas nesta pesquisa, pois a análise fílmica é sempre interminável, além de ser a base da reflexão de caráter teórico e crítico do cinema.

A visão da "mensagem obtusa" de Barthes remete a uma apreensão da obra cinematográfica pelo viés fílmico e poético. 0 sentido obtuso, portanto, excede os patamares da mensagem óbvia e direta, que volta-se ao informativo e simbólico. E, é nessa descontinuidade e desordem da objetividade - aspectos da dimensão do sensível -, que serão desenvolvidas as análises dos dois filmes em preto e branco selecionados. "Se não se pode descrever o sentido obtuso, é que, contrariamente ao sentido óbvio, ele nada copia: como descrever aquilo que nada representa?" (BARTHES, 1982, p. 55, tradução nossa).

Justifica-se a escolha dessas obras pela ênfase com que o cineasta pontua essas duas produções em sua vida, desenvolvendo assim uma certa "proteção pelas esferas do bem" (A ILHA DE BERGMAN, 2006). Há também a pertinência de retomar as obras clássicas de Bergman pela possibilidade de abrir horizontes para pensar o cinema, as artes e o complexo mundo contemporâneo. Além do que, o exercício de leitura da mensagem cinematográfica origina-se de áreas interdisciplinares.

Bergman sonhou rodar o filme Através de um espelho (1961) nas Ilhas Orkney, arquipélago localizado no Mar do Norte (Escócia), mas os produtores por questões econômicas aconselharam-no a explorar a plana Ilha de Farö, de $102 \mathrm{~km}^{2}$, localizada no mar Báltico. Bergman aceitou a contragosto, mas ao pisar na ilha sueca ficou encantado. Farö é uma sucessão natural de árvores, praias, rochas, areias, lagos e recifes moldados pelo vento. A Ilha de Farö é lugar especial em que também filma Persona (1966) e recorda-se, no documentário de Marie Nyreröd, que naquele momento, havia dito ao diretor de fotografia Sven Nykvist: “[...] um dia irei viver por aqui.” (A ILHA DE BERGMAN, 2006). 


\section{A llha de Bergman: foco no essencial}

A residência de Bergman é construída de madeira, iluminada por grandes janelas e escondida entre árvores, tendo sido a principal locação da entrevista que a cineasta Marie Nyreröd fez com o consagrado diretor aos seus 86 anos, em 2004, no filme $A$ ilha de Bergman (2006). Nyreröd conta que foi preciso cinco anos para convencê-lo a participar do documentário, resgatando assim uma exposição de sua vida e uma sistematização de suas ideias. Ela conheceu Bergman em 1983, quando atuava como jornalista para a TV sueca. Em 1997, conseguiu uma entrevista mais despojada e sentiu que era o momento para desenvolver o projeto do documentário.

É nesse ambiente natural de paisagem quase lunar, que Bergman relata a sua infância, quando convence o irmão mais velho Dag para trocar o "aparelho cinematógrafo", à base de lamparina e manivela manual, com o seu "exército de 59 soldadinhos" (A ILHA DE BERGMAN, 2006). Também se recorda da importância de Victor Sjöström, diretor artístico da Svensk Filmindustri e ator principal de Morangos silvestres (1957), que "[...] ofereceu minha primeira verdadeira lição de como fazer filmes e, sobretudo, de como tratar as pessoas com as quais trabalhávamos." (A ILHA DE BERGMAN, 2006).

Depois do sucesso no Festival de Cannes com Sorrisos de uma noite de amor (1955), a Svensk Filmindustri evita interferir em sua criação. Bergman então começa a desenvolver estilo cinematográfico baseado em suas experiências de vida: desafios amorosos, conflitos internos, reflexões filosóficas, limites profissionais, traumas infantis. "Não tive ninguém para discutir meus roteiros, gostaria de ter tido alguém da profissão, até para que quando o filme estivesse pronto eu poderia mostrar e ter uma opinião honesta." (A ILHA DE BERGMAN, 2006).

O documentário de Nyreröd mostra o afresco pintado com o tabuleiro de xadrez, de Albertus Pictor, concebido em 1480, no retábulo da igreja Härkeberge em Uppsala (Suécia), referência à infância de Bergman. A imagem retrata um cavaleiro jogando xadrez com a morte (representada por um homem nu com a cabeça em forma de caveira). Na cena, a morte toma a iniciativa da jogada. A pintura sintetiza o argumento e o impacto de $O$ sétimo selo (1956), considerando a morte como parte inevitável da vida. Bergman questiona no filme se poderíamos conquistá-la, ou, no mínimo, adiá-la.

O diretor sueco relembra a paisagem extraordinária de $O$ sétimo selo (1956), que faz lembrar a Ilha de Farö, no encontro entre o cavaleiro e a morte à beira-mar para o célebre jogo de xadrez. 
0 cerne deste filme é o medo insano da morte. Eu estava num estado horrendo de sofrimento e tormento. Eu tinha muito medo da morte. Tudo relacionado à morte era horrível. Desse horror e do temor da bomba atômica surgiu essa história sobre a peste e a viagem de volta. E, é claro, havia toda a questão representada pela religião. Existe Deus? Não existe Deus? O sétimo selo não traz uma resposta para essa questão. (A ILHA DE BERGMAN, 2006).

Para Bergman, a dualidade diante da presença de Deus e da morte é constante desassossego. Não por acaso, ele decide residir na Ilha de Farö ao final de sua vida, pois seus trabalhos lidam com questões existenciais: fé, amor, beleza, solidão e mortalidade. Suas primeiras impressões da ilha foram em abril de 1960, quando fazia as preparações para filmar Através de um espelho (1961): "Senti algo especial, uma estranha sensação de ter chegado em casa... e aqui respeitam minha necessidade de solidão." (A ILHA DE BERGMAN, 2006).

Figura 1 - Imagem de ensaio do filme O Silêncio (1962) com o diretor Ingmar Bergman e o ator Jörgen Lindström.

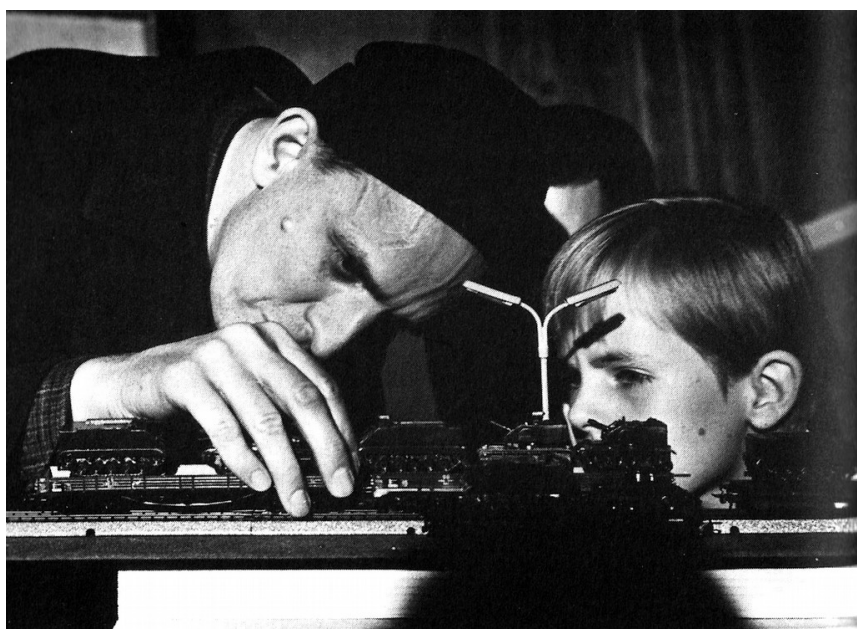

Fonte: Imagens (1996), p. 410.

(c) foto: Sven Nykvist, 1962.

Bergman viveu com as duas atrizes principais do filme Persona (1966), Bibi Andersson e Liv Ullman: “[...] tenho orgulho delas, são mulheres maravilhosas e talentosas, que me ensinaram muitas coisas." (A ILHA DE BERGMAN, 2006). Ele brinca que a sua puberdade encerrou-se aos 58 anos e por isso esteve casado cinco vezes, reconhecendo entretanto uma certa desatenção com os filhos (Figura 1): "Teatro e cinema são duas atividades de imensa carga erótica, havendo uma relação entre a busca da perfeição e a tensão prazerosa." (A ILHA DE BERGMAN, 2006).

A partir da morte de sua mãe, o diretor relata a ideia original de escrever o roteiro de Gritos e sussurros (1971): “[...] tive relação ambígua com ela, que é representada por quatro 
mulheres diferentes.". Bergman reconhece que tanto em Persona (1966)como em Gritos $e$ sussurros (1971), a criatividade artística na dimensão do poético foi como terapia para períodos pessoais conturbados. "Persona salvou a minha vida, além de ser um grande filme ficando feliz por ter podido fazê-lo, e Gritos e sussurros foi confortante e tranquilizante." (A ILHA DE BERGMAN, 2006).

Vale destacar um detalhe curioso sobre a vinda de Marie Nyreröd a São Paulo para a $42^{\text {a }}$ Mostra Internacional de Cinema de São Paulo (2005), quando venceu com $A$ ilha de Bergman(2006) como o melhor documentário estrangeiro. E relata que, quando Bergman soube que a cineasta viria à capital paulista exibir o audiovisual, ele havia sinalizado ter boas lembranças de São Paulo por ter sido uma das primeiras cidades do mundo a reconhecer o seu trabalho.

\section{Sétimo Selo: a santidade dentro do homem}

Por que somos seres humanos com medo da morte? A dualidade vida-morte é o cerne do filme $O$ sétimo selo (1956), uma espécie de road movie em que dois viajantes percorrem a Europa durante a Baixa Idade Média envolta pela morte negra (peste bubônica), Inquisição (Santo Ofício) e Cruzadas (guerra santa). Os dois heróis agem como peregrinos místicos para que a viagem interior seja de fato a "grande viagem". A ideia cênica é o percurso em torno dos dois personagens centrais em que as experiências no caminho final estruturam a narrativa. 0 oceano, o campo e os pequenos vilarejos são apresentados como elementos geográficos de referência, pois o roteiro é definido como memória cultural do velho continente. 0 filme ganha relevância arquetípica e mítica, permitindo refletir sobre a dinâmica da vida cotidiana diante do enfrentamento da morte e pelo retorno à simplicidade do viver.

A viagem tem as virtudes do prazer, descobertas e encontros inusitados. É simultaneamente aventura, conhecimento, conquista de si e beleza: passagem pelos desfrutes e dificuldades da vida. Para o cavaleiro Antonius Blok (Max Von Sydow), a jornada ganha um isolamento natural pelo desejo de reflexão, autoconhecimento e busca interior, diferentemente da figura do escudeiro (Gunnar Björnstrand). Blok liberta-se da necessidade de companhia e das palavras inúteis e vazias. Na língua inglesa há a derivação linguística de diferentes maneiras de estar só: loneliness e aloneness. A primeira palavra está relacionada à solidão, mas a segunda, neste caso, significa estar em companhia de você mesmo com objetivos nobres para refletir e meditar. Ou seja, aloneness não significa estar solitário isolado, mas acompanhado por altos ideais e pela "razão sensível" (MAFFESOLI, 2019, p. 74). 
A viagem como busca interior, portanto, pode ser relacionada ao significado da palavra aloneness. 0 caminho de peregrinação, cuja rota tem caráter religioso ou místico, é campo fértil para reciclar-se e conhecer pessoas em busca da verdade sempre em transformação. Ao resolver viajar sozinho em busca de si mesmo, Blok se depara com o momento aloneness do nascimento e da morte. Entretanto, para esse fim, não é necessário o longo movimento estradeiro ao Oriente, tampouco a lugares sagrados.

0 argumento do filme é o jogo entre a fé e a dúvida em época de crise, portanto nada mais contemporâneo. Ou a crença e a descrença. Bergman tem a liberdade de alterar dados do passado histórico. Não é por acaso, que se inspira na cantata cênica de Carl Orff, Carmina Burana (1935-1936), baseada nas músicas populares de viajantes medievais, peregrinos sem teto e sem identidade. A cantata é inspirada pelo símbolo da Antiguidade: a roda da fortuna girando alternadamente entre a boa e a má sorte. Ou seja, uma parábola da vida humana exposta a constantes mudanças. O cineasta destaca a atração por trabalhar com representações da Idade Média. "A ideia dessa gente que vivia a queda da civilização e cultura, criando contudo novas canções, achei ser matéria sedutora." (BERGMAN, 1996, p. 230).

0 trabalho audiovisual apresenta alguns descuidos históricos, mas é compensado por certo atrevimento artístico, misto de aventura e coragem. Ele vivencia a fé de sua infância ingênua, acreditando que deveria haver a "[...] possibilidade de salvação para além desse mundo." (BERGMAN, 1996, p. 234). A experiência das orações diárias eram práticas de seu pai pastor luterano. De fato, o ideal pastoral corresponde à narrativa dos viajantes pela integração entre homem, animal e terra, ou seja, pelo retorno à essência humana.

Os medievais faziam as grandes peregrinações, como ir a Santiago de Compostela na Espanha. As Cruzadas começaram como coisa digna: recuperar Jerusalém tomada pelos árabes. Sem desconsiderar que muito se deve aos árabes por terem dado consistência às tradições cristãs. Mas à medida que as Cruzadas continuaram, elas se desviaram dos objetivos. Ou seja, a chamada religiosa passa a se tornar negócio e manipulação. É assim a partir da terceira à nona Cruzada, concluída em 1272. E quem vai à procura de um processo religioso, como o cavaleiro Antonius Blok, encontra algo distorcido e sem chão [...] (MÜLLER, 2015, np.).

Realizado em 35 dias, tanto nos estúdios Svensk Filmindustri em Estocolmo como em locações externas, a produção do filme lida com áreas artísticas convergentes: cinema, fotografia, teatro, pintura, escultura, literatura e música. 0 pensamento do cineasta expresso por meio de recursos metalinguísticos é construído como unidade estética. Pela acentuação do único foco - a realidade da morte - procura-se alcançar a intensificação dos meios 
expressivos para levar o efeito ao ápice final. 0 palco teatral é nítida referência, pois $O$ sétimo selo (1956) tem como base a peça em um ato, que Bergman escreveu para os alunos do primeiro ano da Escola de Teatro de Malmö com o título $O$ retábulo da peste. Na busca de Bergman, o cavaleiro Blok é o guerreiro, representante do universo masculino no embate para desafiar a morte.

Cada arte tem uma linguagem própria, com seus meios próprios. Nesse sentido, cada arte é completa em si mesma. Cada arte tem sua própria vida. Ela é um reino em si mesma. Por isso, os meios das várias artes são exteriormente muito diversos. Som, cor, palavra! Em seu fundamento interior mais profundo, esses meios são totalmente iguais: seu objetivo último apaga as diferenças exteriores e revela a identidade interior. (KANDINSKY; MARC, 2013, p. 191)

Bergman transforma o trabalho teatral original, substituindo-o por outro, regido pela imagem fílmica e poética. Nada é óbvio ou objetivo. 0 fato da maior parte da produção ter sido feita em estúdio, com poucos recursos e durante breve tempo, sugere que o autordiretor conservou as mesmas ideias do cenário de palco. De fato, não se camufla a origem teatral e o valor da mensagem. 0 crítico de cinema francês André Bazin (1918-1958) discute as possibilidades de uma peça teatral se tornar cinema.

Comparo romance literário e teatro, mas tudo leva a crer que o raciocínio vale ainda mais para o cinema; pois, das duas uma: ou o filme é a pura e simples fotografia da peça (portanto, com seu texto), e isso é precisamente o famoso "teatro filmado", ou a peça é adaptada às "exigências da arte cinematográfica", mas então recaímos na indução e se trata, de fato, de outra obra. (BAZIN, 2014, p. 162).

Figura 2 - Fotograma do filme 0 sétimo selo (1956) com o ator Bengt Ekerot.

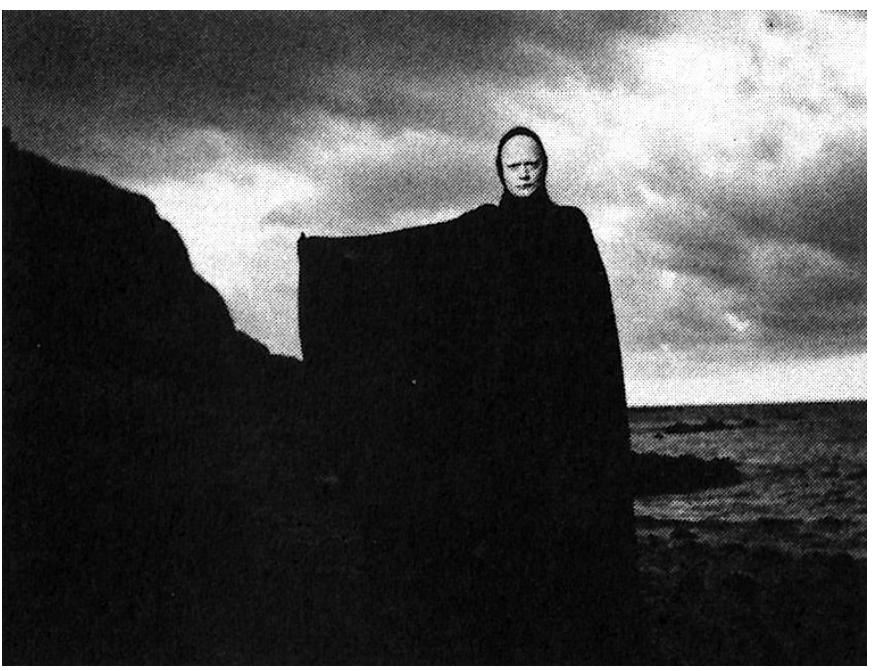

Fonte: Imagens (1996), p. 227.

(c) foto: Gunnar Fischer, 1956. 
O recurso pelo silêncio fílmico propicia adentrar a uma elevação da narrativa. Não por acaso, O sétimo selo (1956) foi premiado pelo Festival de Cannes de 1957. Certos elementos iniciais acentuam a dimensão mítica, enigmática e solene do sentido obtuso: o som do gongo, o voo do pássaro, o mar em plano geral, a quietude abismal. Tudo contribui como atmosfera para os surgimentos da praia de pedras, cavaleiro Blok, escudeiro e ator representando a morte (Bengt Ekerot) - uma alegoria que veste preto e tem o rosto maquiado de branco (Figura 2). Para Bergman, O sétimo selo (1956) acalenta seu coração promovendo vitalidade, força de vontade e ausência de neuroses. Mas há também o resgate da ingenuidade. "Além de ser tema tratado com paixão e prazer, há um armistício entre a crença religiosa de menino e um rude racionalismo de adulto". (BERGMAN, 1996, p. 233).

Entre os personagens, destacam-se o casal de saltimbancos Jof e Mia (Nils Pope e Bibi Andersson) e o pequeno filho. Se por um lado, Bergman questiona os dogmas cristãos, buscando a espiritualidade, por outro lado reafirma a tríade familiar do cristianismo (JoséMaria-Jesus). Ou seja, O sétimo selo (1956) segue atual como resistência à intolerância religiosa em tempos obscuros. No enredo, o trio escapa da morte, evidenciando a sobrevivência da família e a perenidade da arte. 0 malabares Jof comenta em certo momento do filme: "as pessoas parecem não gostar da arte". (O SÉTIMO SELO, 1956). Jof simboliza a inspiração artística. Ele coloca-se, portanto, de fora do jogo e distante dos muros da cidade. Não por acaso, Jof e Mia oferecem ao cavaleiro Blok o "néctar dos deuses": coalhada com morangos silvestres.

Jof também pressente a dança final, em que a morte conduz seis personagens do filme para a ascensão na montanha - início de viagem a outra vida? No final das filmagens, Bergman relata que quando avistou por acaso um pôr do sol no jogo dual entre o céu e as nuvens, aproveitou a cena em contraluz para incluir alguns assistentes de produção e turistas que estavam na vila sueca de Hov. A equipe de atores improvisada não tinha noção do que fazia, foi pedido apenas para dançar e seguir o movimento do grupo.

Em se tratando de Idade Média, a referência literária do cavaleiro e seu escudeiro vem de Dom Quixote de Miguel de Cervantes. Ou seja, a angústia dos pensamentos filosóficos do cavaleiro em contraposição à superficialidade mundana do escudeiro. A dualidade - vida e morte - combina com o antagonismo de Dom Quixote de La Mancha e Sancho Pança. A narrativa fílmica foi inspirada no traço anárquico e aventureiro de Cervantes. "Viajar seria um dos primeiros sonhos a inflamar o espírito de Cervantes. Viveria eternamente sob o signo da insegurança e da aventura." (BROCA, 2002, p. 25).

"Quero o conhecimento, não a fé ou a presunção" (O SÉTIMO SELO, 1956), diz o cavaleiro Blok em diálogo com a morte. Nessa cena, não fica claro ao espectador quem dos 
dois estaria por detrás das grades de uma prisão. Ou seja, estamos fadados a morrer, inclusive a própria morte. Não por acaso, o jogo de xadrez empreendido pelo cavaleiro e a morte é o cerne da narrativa. A morte com as pedras pretas já antecipa: "não posso adiar!" (O SÉTIMO SELO, 1956). Entretanto, o cavaleiro evita dar o xeque-mate à morte. Ou seja, diante do mundo trágico e caótico não poderíamos ainda estar prontos para a imortalidade do corpo.

\section{Persona: dimensões do inconcebível}

Por que somos seres humanos com medo do vazio criativo? 0 jogo dual realidadeficção é o cerne do filme Persona (1966), uma sensação da falsa liberdade diante do mundo caótico em que tudo faz parecer "irreal, fantástico, amedontrador ou ridículo" (BERGMAN, 1996, p. 51). Em abril de 1965, enquanto estava acamado com dores provenientes de pneumonia mal curada, Bergman escreve o argumento do filme: “[...] a missão da arte já terá sido substituída por outras forças?" (BERGMAN, 1996, p. 46).

Bergman relata que ao assumir a chefia do Teatro Nacional da Suécia, no início de 1963, a partir de convite do Ministério da Educação, sua relação com a profissão de interpretar adquire maturidade. 0 diretor descreve seu otimismo, vitalidade, lealdade e força no trabalho, que são refletidos no filme O silêncio (1962). Desse modo, atua simultaneamente em duas frentes artísticas: o teatro e o cinema. 0 teatro é arte milenar marcado pela ação efêmera, mas o cinema favorece o testemunho da realização, a câmera ao gerar cópias físicas em rolos de nitrato de celulose documenta fascínio e memória.

Não por acaso, as primeiras cenas de Persona (1966) são pedaços de filme branco. Na palidez da fita, há palavras e depois surge um rosto que mal se distingue. Bergman relembra seus tempos de juventude em que adquiria numa loja de brinquedos rolos de filme de nitrato já utilizado.

Eu colocava trinta, quarenta metros de filme num banho forte de soda cáustica durante meia hora, desfazendo assim a emulsão, pelo que as imagens desapareciam: a fita branca, virgem, transparente, sem nenhuma imagem. Depois, com tintas de várias cores, eu desenhava bonecos novos. Tiras de filme que rolam no projetor, explodindo em curtas sequências de imagens, são coisas que trazia dentro de mim há muito tempo. (BERGMAN, 1996, p. 55).

Filme dos filmes, Persona (1966) abre portas discursivas ao retratar a psicologia dos personagens a partir da estética do close-up, iluminação monocromática e composição. 0 conceito de persona é considerado, na teoria de Carl Gustav Jung (1964), a nossa imagem 
pública ou papel social, mas que pode ser diferente do ser verdadeiro. No teatro, persona é palavra italiana derivada do latim para "máscara", entretanto quando a máscara é utilizada pelo ator há o ressoar de sua voz (per sonare significa "soar através de"). A máscara ou persona também pode não se referir a uma máscara no sentido literal, mas às máscaras sociais que todos nós supostamente vestimos. Bergman desafia a inteligência do espectador, levantando a questão: o que é real, a máscara ou o rosto?

Na ficção, a personagem Elisabet Vogler (atriz Liv Ullman) sofria de mutismo, manifestado em pleno palco teatral numa apresentação da peça Electra de Sófocles. Dá um branco na atriz em cena, que faz remeter à fita branca e transparente das primeiras imagens do filme. "[...] existem momentos em que as ideias estacionárias tendem a prevalecer." (MAFFESOLI, 2019, p. 21). Durante o tratamento médico, a jovem enfermeira Alma (Bibi Andersson), de 25 anos, fala sem parar. 0 nome da enfermeira é palavra-chave no diálogo entre persona (sra. Vogler) e alma (Alma). Assim como Asas do desejo (1987) de Wim Wenders, Persona (1966)pode ser considerado “[...] diálogo entre a vida física-espiritual e a passagem da infância para a maturidade." (AVANCINI, 2012, p. 233).

Paciente e enfermeira aproximam-se e identificam-se, mas a atriz não fala, rejeitando a própria voz, pois deseja silenciar-se e "não quer faltar à verdade" (BERGMAN, 1996, p. 54). Ligado à psicopatologia, mutismo ou mudez é estado de silêncio e imobilidade com não reatividade e ausência da vontade de falar, muito presente em casos de histeria. Mas relativo à neurologia, há a afasia (do grego aphasía, "dificuldade para falar"), evidenciando perda parcial ou total da fala - no caso da sra. Vogler, com a compreensão da linguagem auditiva e sem lesão cerebral.

Persona (1966) pactua com a violência do mundo midiático, mostrando a imagem icônica do século XX do monge Mahayana, Thich Quang Durc, quando ateava fogo em si numa rua de Saigon, em 11 de junho de 1963. o fato hard-news mostrado na televisão, "um tipo de pornografia do terror" (BERGMAN, 1996, p. 59), ocorre durante uma manifestação contra a política religiosa do governo vietnamita de Ngo Dinh Diem. A sra. Vogler, sem tirar o olho da tela televisiva, assiste a autoimolação pública desse mártir budista de 66 anos: "o homem que se queima pela fé que professa" (BERGMAN, 1996, p. 59). A grande força mental e a imobilidade do monge, considerado bodhisattva por seu coração permanecer intacto, mobiliza a atriz e paciente a encurralar-se no canto do quarto hospitalar.

Imagens icônicas do fotojornalismo não buscam a informação noticiosa somente pelo valor intrínseco do que ela representa, "mas sobretudo pelo seu caráter excepcional" (BOURDIEU, 2010, p. 175, tradução nossa). As cenas dos grandes eventos, portanto, destacam o raro, o imprevisível, o sensacional, o dramático e o não óbvio. E há tratamento 
diferenciado da grande mídia internacional, explorando ocorrências emocionais e trágicas, quando tais fatos ocorrem em lugares menos noticiados, como o Sudeste Asiático. A imagem causa indignação pela reação violenta da sra. Vogler, contrapondo a ideia de Roland Barthes de que a linguagem da dramaticidade na comunicação social pode se tornar sem efeito, anestesiando o espectador devido ao excesso de exposição (BARTHES, 2010, p. 26).

Em Persona (1966), a naturalidade dos acontecimentos, bem como dos corpos, das falas e da trilha sonora, faz brotar a sensação de que não existe interpretação. Seria possível obter veracidade na encenação artística? Momentos voltados ao embate cotidiano entre as duas mulheres oferecem toques do real. Na poesia do jogo de espelhos, busca-se a verdade que repousa no silêncio das coisas.

Persona (1966) não discorre apenas sobre situações vividas pelo próprio diretor, mas principalmente sobre o universo feminino. É em torno da ternura e da empatia que as duas atrizes se entendem, se procuram, se escondem, se tocam, se enraivecem, se expressam. Os conceitos de feminilidade e masculinidade são construídos culturalmente. Entretanto, há a percepção de que as tendências psicológicas femininas podem favorecer os sentimentos, humores instáveis, intuições, capacidade de amar, sentir com a natureza e se relacionar com o inconsciente (CHEVALIER, 1989, p. 421).

A anima e o animus são dois arquétipos descritos por Jung como aspectos do inconsciente. Na psiquê do homem, encontra-se a sua expressão como personificação das tendências psicológicas femininas: anima; equivalentemente, no feminino expressa-se uma personificação masculina: animus (JUNG, 1964). Ou seja, a agressividade que é uma característica masculina, pode apresentar-se no animus interiorizado das mulheres. Não por acaso, a enfermeira Alma indignava-se quando a paciente sra. Vogler a ironizava em suas cartas, considerando-a emocionalmente infantilizada.

A filmagem começa de modo inseguro em Estocolmo, mas ganha impulso com a espontaneidade na esfera sentimental de Liv Ullman e Bibi Andersson (Figura 3), adquirindo também expressividade entre a câmera e a equipe técnica nas imagens construídas na Ilha de Farö. Bergman sempre ressalta seu preciosismo, evitando o improviso. "Esse texto foi rigorosamente concebido; apesar disso, nunca repeti cenas em minha vida como nesse filme." (BERGMAN, 1996, p. 64).

Conciliar realidade e fantasia, a Ilha de Farö descortina-se como espaço físico e simultaneamente mágico. Simboliza a situação existencial da sra. Vogler, pertencente a outros lugares, mas a nenhum lugar precisamente (o cenário natural é captado pela estética da fotografia de Sven Nykvist). A jovem enfermeira relata com perturbação a sua vida banal: 
a paixão por homem casado e a decisão pelo aborto. "Por intermédio da sra. Vogler, Alma procura sua própria pessoa, aprende a se conhecer." (BERGMAN, 1996, p. 56).

Figura 3 - Fotograma do filme Persona (1966) com as atrizes Liv Ullman e Bibi Andersson.

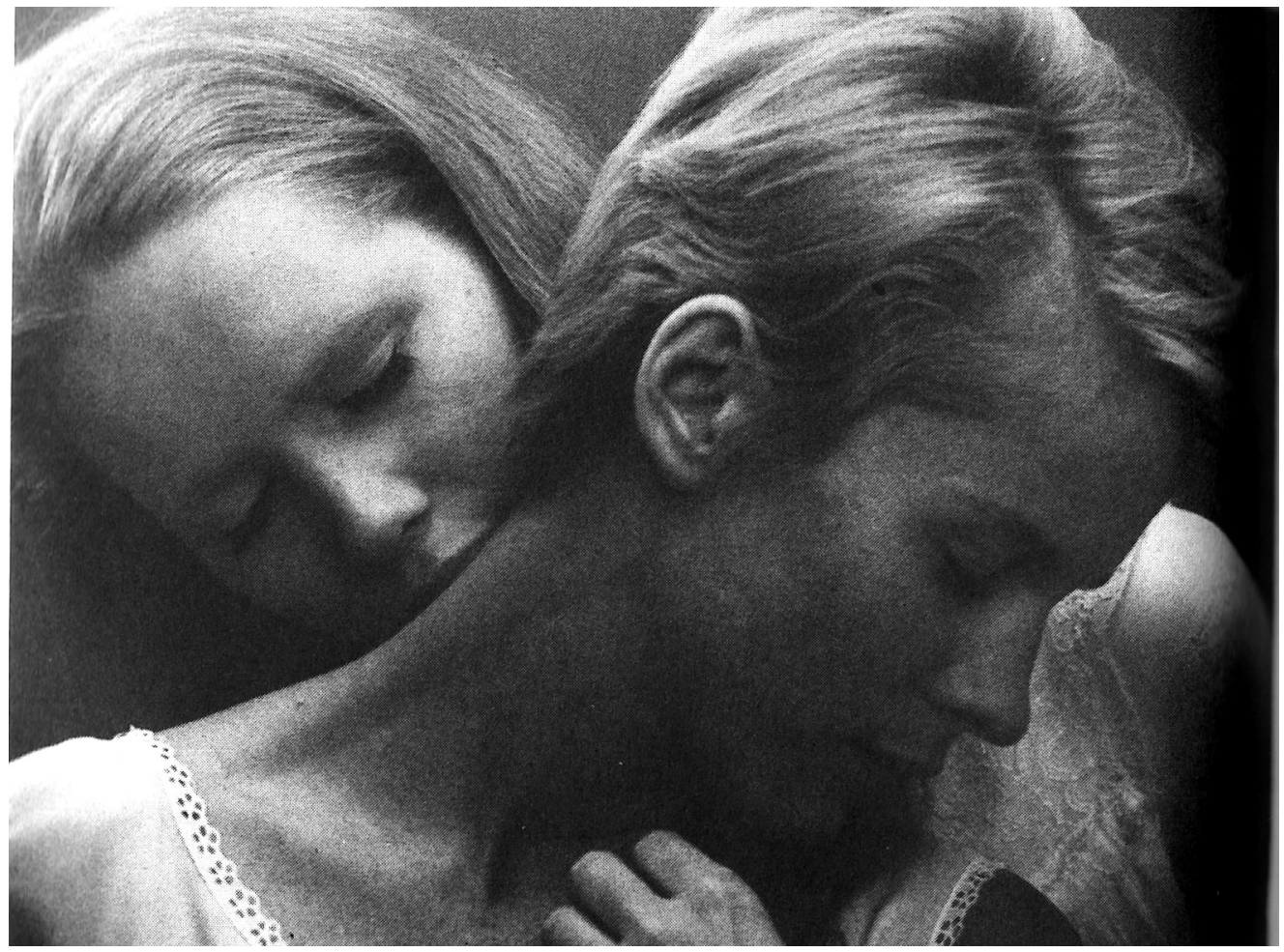

Fonte: Imagens (1996), p. 50.

(c) foto: Sven Nykvist, 1965.

Com isso, o diretor sueco abre mão pela primeira vez de sua máscara social ou aparência para agradar o espectador em geral. A partir de Persona (1966), começa a fazer parte do passado filmes diretos, inteligíveis, cerebrais e condicionados a certos tipos de roteiro que a Svensk Filmindustri procurava impor. A apreensão da arte cinematográfica pelo viés fílmico, a que se refere Barthes como "mensagem obtusa", é a narratividade cênica descontínua que faz aflorar sentimentos: “[...] com total liberdade toco em segredos para os quais não existem palavras e que só a cinematografia pode patentear." (BERGMAN, 1996, p. $65)$.

O diretor sueco trabalha com a sensibilidade, a emotividade e a plasticidade do feminino. No enredo desse monólogo dobrado, combina as metades iluminadas dos dois rostos, "como se fosse uma cena de espelho" (BERGMAN, 1996, p. 61); e evidencia que a paciente e a enfermeira se complementam numa face única. É como se cada uma das duas mulheres pudesse acessar o estado de espírito da outra. Alma afirma, “[...] sentimos culpadas 
por pequenas coisas... você poderia ser eu..." (PERSONA, 1966). Seria possível expor nossas máscaras e alçar o ser essencial?

São duas atrizes tomando parte de um filme ou dois seres fingindo ser personagens? Eduardo Coutinho demonstra em Jogo de cena (2007), unindo realidade e dramaturgia, que ser e representar podem ser uma coisa só. Ou seja, cada um de nós é ator de si mesmo. Seria possível um esforço para extinguir os códigos de representação dos atores profissionais?

\section{Considerações Finais}

A brasileira Helena Beltrame-Linné dirige o Bergmancenter, criado em 2011, que preserva e discute as produções do cineasta por meio de cursos, seminários, cinema, teatro, fotografia, música e dança. A antiga residência de Farö já acolhia o patrimônio da Fundação Bergman: manuscritos, documentos, correspondências, cenários, cartas, registros de entrevistas, filmes. Além do mais, a Ilha de Farö é um parque natural que a sabedoria nórdica sabe proteger da especulação imobiliária, hotéis turísticos e clubes exclusivos. Se o inverno é muito intenso podendo atingir a temperatura de $20^{\circ} \mathrm{C}$ negativos, o verão faz a luz perdurar por quase 24 horas. "Bergman decidiu habitar sobre esta jangada de pedra, metáfora de uma vida reduzida ao essencial." (GARZIA, 2011, p. 4, tradução nossa). Ele escreveu em seu testamento, desejando que a sua residência não se tornasse um museu poeirento, mas uma escola para jovens diretores.

Portanto, o documentário de Marie Nyreröd, por ter sido rodado em Farö, pode metaforizar a arte - e a vida - reduzida ao essencial. 0 filme termina como se inicia: a câmera sobrevoando a Ilha de Farö. Se, no início, aproxima-se e adentra a ilha. No final, há o natural afastar-se. A ilha, a que se chega fisicamente apenas depois de navegação ou de voo, é o símbolo por excelência de um "[...] centro espiritual e, mais precisamente, do centro espiritual primordial." (CHEVALIER, 1989, p. 501). De fato, a ilha constitui a estabilidade em meio à agitação mundana, ou seja, um lugar cercado pela paz e silêncio, bem propício à busca da verdade.

Nos dois filmes discutidos, Bergman buscou o diálogo pelo silêncio, como centro de suas ideias, resgatando a dimensão cênica das dinâmicas da vida para explorar as expressões do rosto humano. No mundo polifônico, isso demonstra a importância da interação em que nada pode ser visto isoladamente. Bergman evidencia que o centro da emoção e expressão da verdade do ser, ou do ator, é o rosto. Na tela, os efeitos da luz sobre os contornos da face humana reagem ao silêncio ou ao som das palavras. A câmera está sempre muito perto, mostrando peles, olhos, bocas, ouvidos, resgatando expressões inteligentes, 
pensativas, entusiasmadas, emotivas e sensuais. Percebe-se o sincronismo no que se refere à iluminação e composição das cenas, seja do fotógrafo Gunnar Fischer em O sétimo selo (1956) ou Svan Nykvist em Persona (1966). Há uma constante união que oferece uma unidade de estilo fazendo do rosto humano o palco central das ações.

Artisticamente, pode-se concluir que Bergman produz forma de pensamento cunhada pelo autoconhecimento e por vivências de dimensão psicológica, metafísica e existencial. A dualidade da vida é constante inquietação, sugerindo em sua obra fílmica o lançar perguntas sem respostas definitivas. 0 diretor encanta-se pelos mistérios da vida, explorando a oposição entre a explosão do êxtase (sair de si próprio) e o silêncio do aquietamento. Ver além do que os olhos enxergam é a mensagem das mensagens, pois julgamos os outros pela imagem e isso não é considerado seguro. Por isso esta análise não está somente situada estruturalmente como existência objetiva, direta, informativa, simbólica e óbvia, mas na força subjetiva e perturbadora do poético, afetivo, descontínuo e obtuso.

A sabedoria popular afirma que é prudente ser econômico no que se diz. Isto é, convém evitar falar para nada dizer. E não faltam palavras banais nas mensagens óbvias da contemporaneidade para disseminar a intriga e o ódio. 0 desvio do ser humano está estruturado na objetividade materialista. Por isso, o exercício do desmarcaramento via busca transgressora dos altos ideais do aloneness empreendido pelos cavaleiro Blok e sra. Vogler. 0 caminho proposto por Bergman a partir das experiências vividas é mais indireto e subjetivo no sentido da percepção da verdade. No fundo isso significa que o próprio ser é fonte original.

Se para o pensamento grego clássico, os demônios foram seres divinos, para Bergman o termo designa os deuses inferiores, ou os espíritos maus que o perseguem. 0 diretor sueco elenca os inumeráveis demônios da vida que circulam por toda a parte: “[...] o desastre, o medo, a raiva, o rancor, o vazio criativo." (A ILHA DE BERGMAN, 2006). Mas, para o enfrentamento da roda da vida, girando alternadamente entre o bem e o mal, há a sinalização de que “[...] os demônios não gostam de ar fresco.” (A ILHA DE BERGMAN, 2006). Ou seja, o conceito de seu cinema é a luz que busca a cultura e a arte, priorizando instantes mágicos de eternidade. 


\section{Referências}

A ILHA de Bergman (Bergman Island). Direção: Marie Nyreröd. Produzido por: Sveriges Television, Suécia, 2006, (83 mins). cor.

ASAS do Desejo (Wings of Desire). Direção: Wim Wenders. Produzido por: Road Movies Berlim, Alemanha, 1987, (128 mins), cor e p\&b.

ATRAVÉS de um Espelho (Through a Mirror Glass). Direção: Ingmar Bergman. Produzido por: Svensk Filmindustri, Suécia, 1961. (89 mins). p\&b.

AVANCINI, Atílio. Asas da história, anjos do desejo. Significação: Revista De Cultura Audiovisual, São Paulo, v. 39, n. 38, p. 227-246, 2012.

BARTHES, Roland. L'obvie et L’obtus. Paris: Éditions du Seuil, 1982.

BARTHES, Roland. 0 Óbvio e o Obtuso. Lisboa: Edições 70, 1984.

BARTHES, Roland. Mythologies. Paris: Éditions du Seuil, 2010.

BAZIN, André. 0 que é o Cinema? São Paulo: Cosac Naify, 2014.

BERGMAN, Ingmar. Imagens. São Paulo: Martins Fontes, 1996.

BOURDIEU, Pierre. Un Art Moyen. Paris: Les Éditions de Minuit, 2010.

BROCA, Brito. Introdução. In: CERVANTES, Miguel de. Dom Quixote de La Mancha. Rio de Janeiro: Ediouro, 2002, p. 23-72. v. 1.

CHEVALIER, Jean. Dicionário de Símbolos. Rio de Janeiro: José Olympio, 1989.

GARZIA, Aldo. L'île d'Ingmar Bergman.Travelling sur Fårö Courrier International. Milano, 30 ag. 2011, p. 4.

GRITOS e sussurros (Viskningar och Rop). Direção: Ingmar Bergman. Produzido por: Svensk Filmindustri, Suécia, 1971. (91 mins). cor.

JOGO de cena. Direção: Eduardo Coutinho. Brasil, 2007. (95 mins). cor.

JUNG, Carl Gustav. L'homme et ses Symboles. Paris: Éditions du Seuil, 1964.

KANDINSKY, Wassily; MARC, Franz. Almanaque 0 Cavaleiro Azul. São Paulo: Edusp;MLS, 2013.

MORANGOS silvestres (Smultronstället). Direção: Ingmar Bergman. Produzido por: Svensk Filmindustri, Suécia, 1971. (91 mins). p\&b.

MAFFESOLI, Michel. A Palavra e o Silêncio. São Paulo: Palas Athena, 2019.

MÜLLER, Nestor. Depoimento a Atílio Avancini. Projeto Ingmar Bergman, Ribeirão Preto (SP), 15 de janeiro de 2015. 
O SÉTIMO selo (The Seventh Seal). Direção: Ingmar Bergman. Produzido por: Svensk Filmindustri, Suécia, 1956. (95 mins). p\&b.

O SILÊNCIO (Tystnaden). Direção: Ingmar Bergman. Produzido por: Svensk Filmindustri, Suécia, 1962. (95 mins). p\&b.

PERSONA (Persona). Direção: Ingmar Bergman. Produzido por: Svensk Filmindustri, Suécia, 1966. (83 mins). p\&b.

SORRISOS de uma Noite de Amor (Sommarnattens Leende). Direção: Ingmar Bergman. Produzido por: Svensk Filmindustri, Suécia, 1955. (108 mins), p\&b.

\title{
Ingmar Bergman's magic moments
}

\begin{abstract}
The article is about the documentary The island of Bergman (2006) by Marie Nyreröd. The aim is to study the cinematographic thought of the director Ingmar Bergman (19182007) when analyzing critically two of his classic works: The seventh seal (1956) and Persona (1965). This research privileges the use of concepts about the cinematographic message within the theoretical method of Roland Bathes' obtuse message. The filmmaker's thought based on existential questions results in the life-death duality and reality-fiction as well as the poetic impact of his ideas for the present moment. Life contradictions are the concerns of the swedish director who launches questions without definitive answers. The conclusion is that his authorial work based on these two films aims to seek perfection and the psychological-existential dimension as well as unveiling the path of interiority.
\end{abstract}

\section{Keywords}

Movie. Photography. Image. Analysis. Memory.

Recebido em 29/04/2019

Aceito em 19/08/2019 